\title{
Urea and DON uptake by a Lyngbya gracialis dominated microbial mat: a controlled laboratory experiment
}

\author{
Jane B. Rondell, Kai W. Finster, Bente Aa. Lomstein* \\ Department of Microbial Ecology, Institute of Biological Sciences, Aarhus University, Building 540, Ny Munkegade, \\ 8000 Aahus C, Denmark
}

\begin{abstract}
The uptake of urea and dissolved organic nitrogen by a Lyngbya gracialis dominated microbial mat was studied in a double chambered continuous flow-through system in a $12: 12 \mathrm{~h}$ light:dark cycle experiment and during a prolonged dark incubation. In addition, the fluxes of total inorganic carbon, oxygen, dissolved free amino acids, nitrate and ammonium across the microbial mat were studied. In the $12: 12 \mathrm{~h}$ light:dark cycle, the microbial mats grew exponentially $\left(0.5 \mathrm{~d}^{-1}\right)$ with dissolved organic nitrogen as a nitrogen source. Dark urea uptakes were 50 to $85 \%$ of the urea uptakes in light. The uptake of urea continued during the $2 \mathrm{wk}$ of prolonged dark incubation. Natural microbial mats may be important regulators of urea dynamics in shallow marine environments, as the microbial mat efficiently took up urea at concentrations somewhat higher than in situ urea concentrations in surface sediments.
\end{abstract}

KEY WORDS: Cyanobacteria $\cdot$ Fluxes $\cdot$ Flow-through system $\cdot$ Microbial mats $\cdot$ Nitrogen retention

\section{INTRODUCTION}

The release of nitrogen from coastal marine sediments can supply 10 to $200 \%$ of the nitrogen requirements of pelagic primary producers (Blackburn \& Henriksen 1983, Klump \& Martens 1983). Measurements of the nitrogen efflux from the sediment to the water column have traditionally included inorganic nitrogen compounds $\left(\mathrm{NH}_{4}{ }^{+}, \mathrm{NO}_{2}{ }^{-}\right.$and $\left.\mathrm{NO}_{3}{ }^{-}\right)$, whereas studies on dissolved organic nitrogen (DON) fluxes from the sediment to the water column are rare (Enoksson \& RüdénBerg 1983, Hopkinson 1987, Boucher \& BoucherRodoni 1988, Hansen \& Blackburn 1991, 1992, Burdige \& Zheng 1998, Lomstein et al. 1998). Urea can be a quantitatively important component of the nitrogen efflux from the sediment to the water column (Boucher \& Boucher-Rodoni 1988, Lomstein et al. 1989), as the efflux of urea can account for 10 to $100 \%$ of the total urea + inorganic nitrogen flux (Lomstein et al. 1989, Lomstein unpubl.)

•Corresponding author. E-mail: bente.lomstein@biology.au.dk
Microbial mats situated on the sediment surface may be important regulators of the exchange of DON between the sediment and the water column in shallow marine environments. Microbial mats are complex communities of photoautotrophic, photoheterotrophic, chemoautotrophic and heterotrophic microorganisms (Jørgensen et al. 1983, Stal et al. 1985). Cyanobacteria are, in many cases, the most important mat-building organisms (Jørgensen et al. 1983). Microbial mats are found in physically and chemically versatile environments such as marine intertidal flats, hypersaline waters and hot springs (Jørgensen et al. 1983, Bauld 1984, Castenholz 1984, Gerdes \& Krumbein 1984, Stal et al. 1985). Numerous field and laboratory investigations have studied the influence of microbial mats on inorganic nitrogen exchange between the sediment and the water column (Henriksen et al. 1980, Andersen \& Kristensen 1988, Sundbäck \& Granéli 1988, Sundbäck et al. 1991, Bebout et al. 1994). However, the impact of microbial mats on benthic urea and DON fluxes has to our knowledge not been studied previously.

The aim of the present study was to evaluate (1) the ability of microbial mats to take up urea supplied from 
below the mat, (2) the diel variation in urea uptake and (3) the effect of a prolonged dark incubation on the uptake of urea. The experiments were conducted in a double chambered continuous flow-through system. The advantage of this system was that physical and chemical parameters such as light intensity, $\mathrm{pH}$, temperature, salinity and nutrient concentrations could be controlled and sediment processes were excluded.

\section{MATERIALS AND METHODS}

Sampling (microbial mat enrichment). Seawater, mud, sand, eelgrass, and mussels were collected from Gammel Løgten Beach (Aarhus Bay, Denmark) and transferred to 3 aquaria. The eeiyrass and inussels were placed on the bottom of the aquaria and covered with a layer of sand. The mud was placed above the sand and finally seawater was added. The 3 aquaria were incubated at $16^{\circ} \mathrm{C}$ in a $12 \mathrm{~h}: 12 \mathrm{~h}$ light:dark cycle. Light was supplied from a fluorescent lamp (Osram L30W/77 fluora) and the light intensity was 90 to $250 \mu \mathrm{E} \mathrm{m}^{-2} \mathrm{~s}^{-1}$. Dense cyanobacterial mats developed after $3 \mathrm{wk}$ of incubation. The mats were dominated by Lyngbya gracialis, but they also contained L. aestuarii, Oscillatoria spp., Beggiatoa spp., diatoms, coccoid cyanobacteria, flagellates such as Exuviaella sp., and unidentified bacteria.

Experimental set-up. Two 251 water reservoirs supplied media to the top and bottom half-chambers, respectively of the experimental continuous flow-through system (Fig. 1). Two Erlenmeyer flasks (500 ml) were inserted between the reservoirs and the chambers, to bubble the medium with sterilised atmospheric air. The Erlenmeyer flasks were submerged into a thermostated water bath $\left(20^{\circ} \mathrm{C}\right)$. A combined bubble trap and a drip system between the pump and each growth chamber captured air bubbles and prevented bacterial contamination of the reservoir media. The complete chamber set-up consisted of a top and a bottom halfchamber, which were connected by a permeable filter membrane overlaid with solidified gelrite (Fig. 1). A detailed description of the filter is given below. The aerated media was pumped through the $50 \mathrm{ml}$ top and bottom half-chambers with a Watson-Marlow pump at a flow rate of $1 \mathrm{ml} \mathrm{min}^{-1}$. The resultant renewal time of water in the top and bottom half-chambers was $50 \mathrm{~min}$. All connections within the system were made of Viton VA 70 (Verneret) tubes. The seawater flowing through the top and bottom half-chambers of the continuous flow-through system was a modified Waterbury (1992) SNAX medium. The medium supplied to the top halfchamber was phosphate-free and contained vitamin $\mathrm{B}_{12}\left(50 \mathrm{pg} \mathrm{l}^{-1}\right)$. The medium supplied to the bottom half-chamber contained urea ( $1 \mathrm{mmol}$ urea- $\left.\mathrm{N} \mathrm{l}^{-1}\right)$. The
SNAX medium was made of seawater from the sampling site and the final $\mathrm{pH}$ and salinity of the medium was 8.2 and $11.6 \%$, respectively. The use of natural seawater as part of the SNAX medium resulted in minor changes in the concentrations of specific compounds between batches.

Inoculation and establishment of the microbial mat. The mats were rinsed with GF/C filtered seawater under dim light in order to remove eelgrass and sand particles. An autoclaved gelrite solution $(0.002 \mathrm{w} / \mathrm{v})$ was pipetted onto the top of an anodisc filter, which was fixed to the bottom of a polycarbonate cylinder (inner diameter $20 \mathrm{~mm}$, height $2 \mathrm{~mm}$; Fig. 1). The rinsed mats were inoculated on top of the gelrite solution immediately after the gelrite solution reached a lemperature of $30^{\circ} \mathrm{C}$. Two top half-chambers were inoculated with mat material. One chamber set-up was used in a light:dark experiment and the other chamber set-up was used in the long-term dark experiment. A third chamber set-up was not inoculated and served as a control. The chambers were placed in a thermostated water bath at $17.0 \pm 0.5^{\circ} \mathrm{C}$.

The growth of the microbial mats was restricted to the filters as phosphate was only supplied to the bottom half-chamber. The water in the top half-chamber was stagnant during the first $2 \mathrm{~d}$ to allow the mat to establish; hereafter the top half-chamber was connected to the flow. The water bodies of the top and bottom half-chambers were stirred with a magnet (60 rpm). The microbial mats were preincubated for an additional $2 \mathrm{~d}$ in a 12:12 h light:dark cycle. Light was supplied from an Osram (41860 SP, $12 \mathrm{~V}$, and $20 \mathrm{~W}$ ) halogen lamp and the light intensity was $35 \mu \mathrm{E} \mathrm{m}^{-2} \mathrm{~s}^{-1}$. The tube system was rinsed with $1 \mathrm{~N} \mathrm{HCl}$ followed by a thorough wash with Milli-Q water the day before the flux measurements were initiated. Day 1 refers to the first day of the flux measurement.

Incubation and sampling. The appropriate sampling time in the light and the dark periods, where steady state was established, was determined in a pilot experiment. In the pilot experiment samples for urea, $\mathrm{O}_{2}$ and $\mathrm{CO}_{2}$ measurements were taken 4 times in the light period and 4 times in the dark period. Urea uptake rates and $\mathrm{O}_{2}$-production and -consumption rates were constant after $\sim 2 \mathrm{~h}$ in the light (urea: $0.516 \pm 0.006 \mathrm{mmol} \mathrm{N} \mathrm{m}^{-2} \mathrm{~h}^{-1}, \mathrm{n}=4$ ) and in the dark $10.455 \pm 0.006 \mathrm{mmol} \mathrm{N} \mathrm{m} \mathrm{N}^{-2} \mathrm{~h}^{-1}, \mathrm{n}=4$; $\mathrm{O}_{2}$-production: $4.26 \pm 0.34 \mathrm{mmol} \mathrm{m}^{-2} \mathrm{~h}^{-1}, \mathrm{n}=4 ; \mathrm{O}_{2}$-consumption: $3.12 \pm 0.74 \mathrm{mmol} \mathrm{m}{ }^{-2} \mathrm{~h}^{-1}, \mathrm{n}=4$ ). $\mathrm{CO}_{2}$-production and -consumption rates were constant after $\sim 4 \mathrm{~h}$ in the dark or in the light $\left(\mathrm{CO}_{2}\right.$ production: $7.12 \pm 0.32 \mathrm{mmol}$ $\mathrm{m}^{-2} \mathrm{~h}^{-1}, \mathrm{n}=3 ; \mathrm{CO}_{2}$ consumption: $5.64 \pm 1.03 \mathrm{mmol} \mathrm{m} \mathrm{m}^{-2}$ $\mathrm{h}^{-1}, \mathrm{n}=3$ ). The results obtained at the first sampling in the light or in the dark period were not included in the calculation of the average $\mathrm{CO}_{2}$ fluxes as steady state was not reached at that time. On the basis of the results ob- 


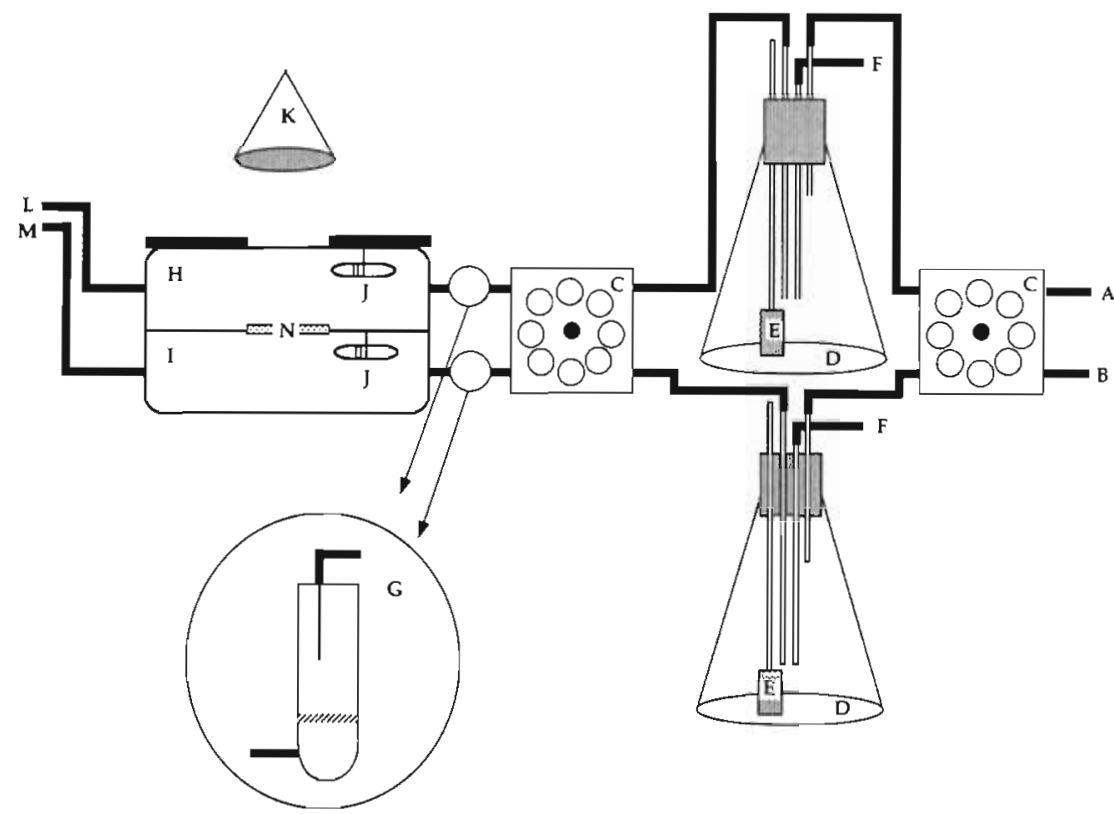

Fig. 1. The double-chambered, continuous flow-through system. (A) medium (25 1 reservoir) for the top half-chamber, (B) medium (25 l reservoir) for the bottom half-chamber, (C) Watson-Marlow pump. (D) $500 \mathrm{ml}$ Erlenmeyer flasks submerged in a thermostated water bath, $(E)$ inlet of sterilized atmospheric air through a bubble stone, (F) sampling of inflowing water to the top and bottom half-chambers, (G) a combined bubble trap and drip system, $(\mathrm{H})$ top half-chamber, (I) bottom half-chamber, (J) Teflon-coated magnet driven by a large rotating magnet (not shown), (K) Osram (41860 SP, 12V, 20W) halogen lamp, (L) sampling of outflowing water from the top half-chamber, $(\mathrm{M})$ sampling of outflowing water from the bottom half-chamber and $(\mathrm{N})$ polycarbonate cylinder on which the anodisc filter was mounted

tained in the pilot experiment it was decided that sampling was to be carried out after $10 \mathrm{~h}$ in the light or in the dark in order to ensure that steady-state conditions were reached.

Two experiments were carried out: (1) a long-term diel study where the microbial mat was exposed to a 12:12 h light:dark cycle (Expt 1) and (2) a study on the effect of a prolonged dark period (Expt 2). The total incubation time in the long-term diel study was $11 \mathrm{~d}$ and sampling of inflow and outflow water took place on Days 1, 2, 5, 7, 8, 10 and 11. In Expt 2 (the prolonged dark incubation), the microbial mat was exposed to a 12:12 h light:dark cycle for $7 \mathrm{~d}$ followed by a $16 \mathrm{~d}$ dark incubation. Sampling was performed as described in Expt 1. On Days 12 and 23 (i.e. after 5 and $16 \mathrm{~d}$ in the dark) the inflow and outflow water was sampled twice a day.

Inflow water was collected from the Erlenmeyer flasks except for samples for the determination of $\mathrm{O}_{2}$. These samples were taken from the $\mathrm{O}_{2}$-collection chambers mounted before and after the growth chamber set-up (Fig. 1). Outflow water was collected from the outflow of the top and bottom half-chambers.
Water samples for the analysis of DON, dissolved free amino acids (DFAA), urea-N, $\mathrm{NH}_{4}{ }^{+}$and $\mathrm{NO}_{3}{ }^{-}$ were filtered through a $0.2 \mu \mathrm{m}$ Sartorius filter and frozen for later analysis. Samples for the determination of total inorganic carbon $\left(\mathrm{C}_{\mathrm{T}}=\mathrm{HCO}_{3}{ }^{-}+\mathrm{CO}_{3}{ }^{2-}\right.$ $+\mathrm{CO}_{2}$ ) were collected in $6.5 \mathrm{ml}$ gastight vials (Labco, Exetainers), conserved with $40 \mu \mathrm{l} 5 \%(\mathrm{w} / \mathrm{v}) \mathrm{HgCl}_{2}$ solution and stored in the dark at $5^{\circ} \mathrm{C}$ for later analysis. The samples were never stored for more than 2 wk. $\mathrm{O}_{2}$ samples were pumped with a peristaltic pump (LKB BROMMA, BRD) from the $\mathrm{O}_{2}$-collection chamber to a chamber equipped with an $\mathrm{O}_{2}$ microelectrode for direct measurement of the $\mathrm{O}_{2}$ concentration (Revsbech 1989)

Analytical procedure. The concentrations of urea- $\mathrm{N}$ and $\mathrm{NH}_{4}{ }^{+}$were measured on a Technicon Autoanalyzer by the diacetylmonoxime method described in Price \& Harrison (1987) and the salicylate-hypochlorite method (Bower \& Holm-Hansen 1980), respectively. The concentration of $\mathrm{NO}_{3}{ }^{-}$was analysed by HPLC (Sykam, Gilching, Germany) equipped with an UV detector (SpectroMonitor 3200) at a wavelength of $220 \mathrm{~nm}$. The eluent was $20 \mathrm{mM} \mathrm{NaCl}$

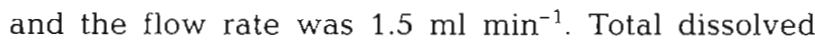
nitrogen (dissolved organic + inorganic nitrogen) was analysed on a modified Antek 7000 system as described in Lomstein et al. 1998). The concentration of $\mathrm{C}_{\mathrm{T}}$ was measured on a flow injection system as described by Hall \& Aller (1992). DFAA concentrations were determined by high performance liquid chromatography (HPLC; Waters Chromatographic System) according to Lindroth \& Mopper (1979).

Calculations. The fluxes $(F)$ of gasses and dissolved compounds across the microbial mat-water interface were, with the exception of the urea flux, calculated by use of the Nishio et al. (1983) formulation:

$$
F=V\left(C_{0}-C_{i}\right) / A
$$

where $V$ is the flow rate, $C_{1}$ is the concentration in the inflowing water, $C_{0}$ is the concentration in the outflowing water and $A$ is the surface area of the mat $\left(A=3.1 \mathrm{~cm}^{2}\right)$. The net urea fluxes were calculated from the concentration difference in the top halfchambers of the inoculated set-up and the control setup. The net uptake rates of DON, urea-N, DFAA, $\mathrm{NH}_{4}{ }^{+}, \mathrm{NO}_{3}{ }^{-}$and $\mathrm{C}_{\mathrm{T}}$ and the net production rate of $\mathrm{O}_{2}$ 
by the microbial mat were calculated as the difference between the net fluxes in the control chamber set-up and the microbial mat chamber set-up. Gross primary production was calculated as $C_{T}$ uptake in light plus dark $\mathrm{C}_{\mathrm{T}}$ release. It was assumed that respiration in the light equalled the measured dark respiration.

The C:N uptake ratio by the microbial mat was determined as the gross primary production divided by the DON uptake. The average C:N uptake ratio given in the discussion is the mean of the $C: N$ ratios obtained on Days 8, 10 and 11 in Expt 1.

\section{RESULTS}

The diffusion of urea- $\mathrm{N}$ from the bottom half-chamber to the top half-chamber of the control chamber setup resulted in a urea- $\mathrm{N}$ concentration in the top halfchamber of 5.8 to $6.8 \mu \mathrm{M} \mathrm{N}$. Differences in the urea concentration in the SNAX medium resulted in slightly variable urea- $\mathrm{N}$ concentrations in the control top halfchambers. The urea concentration in the top half-chamber in the long-term diel experiment varied between 1.9 and $3.28 \mu \mathrm{M}$ in the light and 3.09 and $4.32 \mu \mathrm{M}$ in the dark. In the prolonged dark experiment the concentration varied between 1.0 and $1.4 \mu \mathrm{M}$ in the light and 2.0 and $3.5 \mu \mathrm{M}$ in the dark. The variation in the urea concentration was due to differences in the urea concentration in the batch of natural seawater, which was used for the modified SNAX medium. The difference in the $\mathrm{O}_{2}$ concentration in the inflow and outflow water of the top half-chamber of the control chamber set-up was 1 to $2 \mu \mathrm{M}$. However, the $\mathrm{O}_{2}$ concentration in the inflow water changed from $258 \mu \mathrm{M}$ in the beginning of the experiment to $224 \mu \mathrm{M}$ on Day 10. After Day 10 the $\mathrm{O}_{2}$ concentration remained constant. In the long-term diel experiment the $\mathrm{O}_{2}$ concentration in the outflow water differed, with $\sim 70 \mu \mathrm{M}$ between light and dark conditions. The lowest out flow $\mathrm{O}_{2}$ concentration obtained in the dark was $210 \mu \mathrm{M}$ and the highest concentration in the light was $282 \mu \mathrm{M}$. A similar difference in the outflow $\mathrm{O}_{2}$ concentration between light and dark was obtained during the light:dark cycles (first 7 d) of the prolonged dark experiment. The DON concentration in the inflow water fell in the range of 5.6 to $11.6 \mu \mathrm{M}$ dependent on the batch of seawater that was used for the modified SNAX medium. The $\mathrm{C}_{\mathrm{T}}$ concentration in the inflow water varied between 1750 and $1900 \mu \mathrm{M}$, which was also dependent on the seawater batch used for the modified SNAX medium.

\section{Long-term diel experiment}

The diel variation in the net fluxes of $\mathrm{O}_{2}, \mathrm{C}_{\mathrm{T}}$ and DON and in the uptake of urea during the $11 \mathrm{~d}$ of incubation is shown in Fig. 2. There was a net production of $\mathrm{O}_{2}$ and a net uptake of $\mathrm{C}_{\mathrm{T}}$ by the microbial mat in the light, except during the first $2 \mathrm{~d}$ of incubation, when there was a net uptake of $\mathrm{O}_{2}$ and a net production of $\mathrm{C}_{\mathrm{T}}$ (Fig. 2a,b). The net production of $\mathrm{O}_{2}$ and the $\mathrm{C}_{\mathrm{T}}$ uptake in the light varied between 2.8 and $11.3 \mathrm{mmol} \mathrm{O}_{2} \mathrm{~m}^{-2}$ $\mathrm{h}^{-1}$ and 4.1 and $12.1 \mathrm{mmol} \mathrm{C}_{\mathrm{T}} \mathrm{m}^{-2} \mathrm{~h}^{-1}$, respectively, during the remaining part of the experiment. Net dark $\mathrm{O}_{2}$ uptake and $\mathrm{C}_{\mathrm{T}}$ production rates varied between 1.7 and $6.6 \mathrm{mmol} \mathrm{O}_{2} \mathrm{~m}^{-2} \mathrm{~h}^{-1}$ and 0.6 and $5.3 \mathrm{mmol} \mathrm{C}_{\mathrm{T}} \mathrm{m}^{-2}$ $\mathrm{h}^{-1}$, respectively, from Day 5 to Day 11 . The gross primary production rate increased from $93.4 \mathrm{mmol} \mathrm{C} \mathrm{m}^{-2}$ $\mathrm{d}^{-1}$ on Day 5 to $154.1 \mathrm{mmol} \mathrm{C} \mathrm{m} \mathrm{m}^{-2} \mathrm{~d}^{-1}$ on Day 8. After Day 8 the gross primary production remained almost constant (150.7 to $151.7 \mathrm{mmol} \mathrm{C} \mathrm{m}^{-2} \mathrm{~d}^{-1}$, data not shown). There was an exponential increase in the cumulated net primary production by the microbial mat during the time span of the incubation (Fig. 3) and the growth rate constant was $0.5 \mathrm{~d}^{-1}$

There was a net uptake of DON by the microbial mat in both light and dark from Day 8 . The DON uptake rates varied between 0.5 and $0.8 \mathrm{mmol} \mathrm{N} \mathrm{m}^{-2} \mathrm{~h}^{-1}$ (Fig. 2c). On Days 5 and 7, there was a release of DON in the light of 0.7 and $0.6 \mathrm{mmol} \mathrm{N} \mathrm{m}^{-2} \mathrm{~h}^{-1}$, respectively, whereas DON was released in the dark on Day 5 $\left(0.3 \mathrm{mmol} \mathrm{N} \mathrm{m}^{-2} \mathrm{~h}^{-1}\right)$ and taken up in the dark on Day 7 $\left(0.5 \mathrm{mmol} \mathrm{N} \mathrm{m}^{-2} \mathrm{~h}^{-1}\right)$. It was not possible to calculate a flux of DFAA, as the concentration of DFAA was always below the detection limit of the analytical system. The microbial mat took up urea- $N$ in both light and dark, but the uptake rates were higher in the light

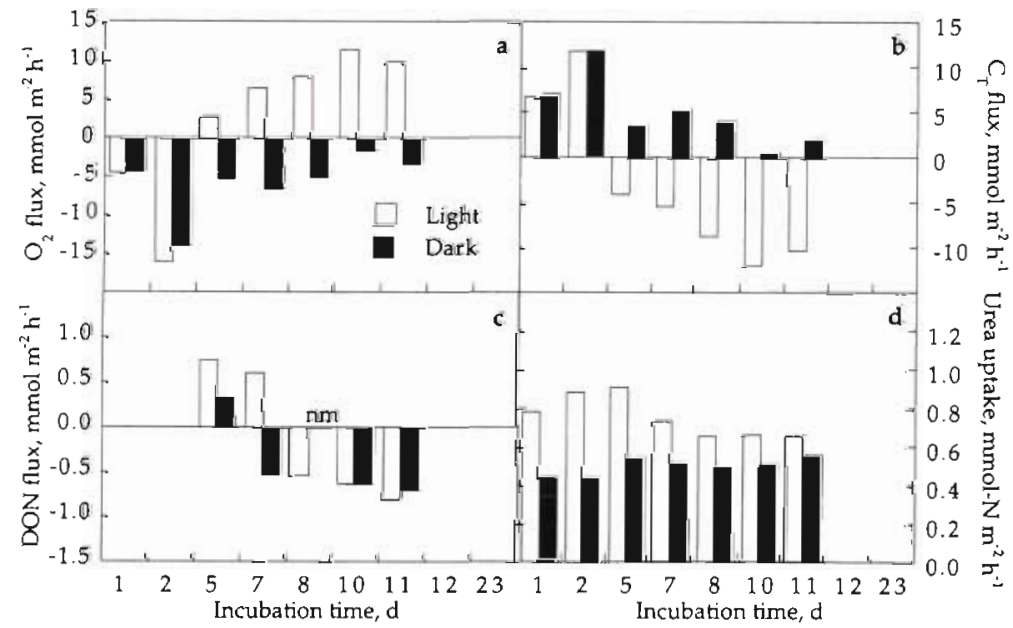

Fig. 2. Diel variation in net fluxes of $(\mathrm{a}) \mathrm{O}_{2}$, (b) total inorganic carbon $\left(\mathrm{C}_{\mathrm{T}}\right)$, (c) DON and (d) net urea-N uptake during the $11 \mathrm{~d}$ of incubation in the long-term diel experiment. The net DON fluxes given in (c) are fluxes of DON other than urea 


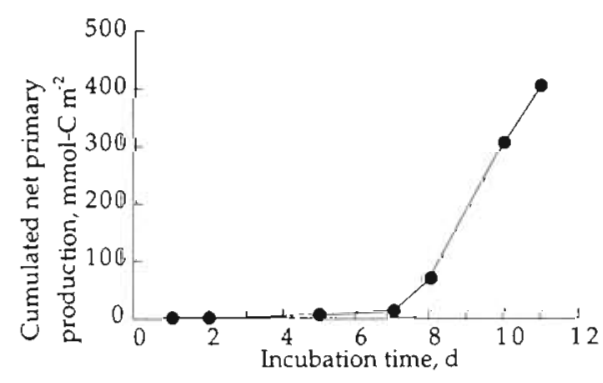

Fig. 3. Cumulated net primary production of the microbial mat in the long-term diel experiment

than in the dark (Fig. 2d). Light and dark urea-N uptake rates varied between 0.7 and 0.9 and between 0.4 and $0.6 \mathrm{mmol} \mathrm{N} \mathrm{m}^{-2} \mathrm{~h}^{-1}$, respectively, during the 11 $\mathrm{d}$ of incubation. The difference between light and dark urea- $\mathrm{N}$ uptake rates decreased with increased time of incubation. $\mathrm{NH}_{4}^{+}$was taken up by the microbial mat during the first $2 \mathrm{~d}$ of incubation, where the uptake rates were 0.8 and $1.1 \mathrm{mmol} \mathrm{m}^{-2} \mathrm{~h}^{-1}$, respectively (data not shown). $\mathrm{NO}_{3}{ }^{-}$was not taken up by the microbial mat, despite the $\mathrm{NO}_{3}{ }^{-}$concentration in the inflowing water being 35 to $43 \mu \mathrm{M}$ during the entire experiment.

The total uptake of DON + urea-N by the microbial mat increased from $4.5 \mathrm{mmol} \mathrm{N} \mathrm{m}^{-2} \mathrm{~d}^{-1}$ on Day 5 to $32.6 \mathrm{mmol} \mathrm{N} \mathrm{m}^{-2} \mathrm{~d}^{-1}$ on Day 11. This change was mainly due to the fact that the microbial mat was a source of DON other than urea in the beginning of the experiment, whereas it was a sink for both DON and urea during the remaining part of the experiment.

\section{Effect of a prolonged dark incubation}

The effects of a prolonged dark incubation on net $\mathrm{O}_{2}$ and DON fluxes and the uptake of urea are shown in Fig. 4. Prior to the dark period (Day 7), the net fluxes of $\mathrm{O}_{2}$ and DON and the urea-N uptake in the light and in the dark were similar to the respective light and dark rates obtained on Day 7 in the long-term diel incubation (see Fig. 2a,c,d). Due to analytical problems, $\mathrm{C}_{\mathrm{T}}$ was not measured during the prolonged dark incubation.

There was a decrease in the $\mathrm{O}_{2}$ uptake from Day 8 (3.9 $\left.\mathrm{mmol} \mathrm{O}_{2} \mathrm{~m}^{-2} \mathrm{~h}^{-1}\right)$ to Day $10\left(1.5 \mathrm{mmol} \mathrm{O}_{2} \mathrm{~m}^{-2} \mathrm{~h}^{-1}\right)$; hereafter the $\mathrm{O}_{2}$ uptake remained low $(1.6$ to $2.1 \mathrm{mmol}$ $\mathrm{O}_{2} \mathrm{~m}^{-2} \mathrm{~h}^{-1}$, Fig. 4a). The net uptake of DON was higher during the first $3 \mathrm{~d}$ of the prolonged dark incubation ( 0.3 to $1.2 \mathrm{mmol} \mathrm{N} \mathrm{m}^{-2} \mathrm{~h}^{-1}$ ) than the dark uptakes of DON in the same period in the long-term diel incubation. The dark DON uptake rates varied between 0.6 and $0.7 \mathrm{mmol} \mathrm{N} \mathrm{m}^{-2} \mathrm{~h}^{-1}$ in the long-term diel incubation (compare Fig. 4b and Fig. 2c). The uptake of urea remained unchanged in the prolonged dark incubation (Fig. 4c) compared to the dark uptake of urea in the long-term diel incubation.

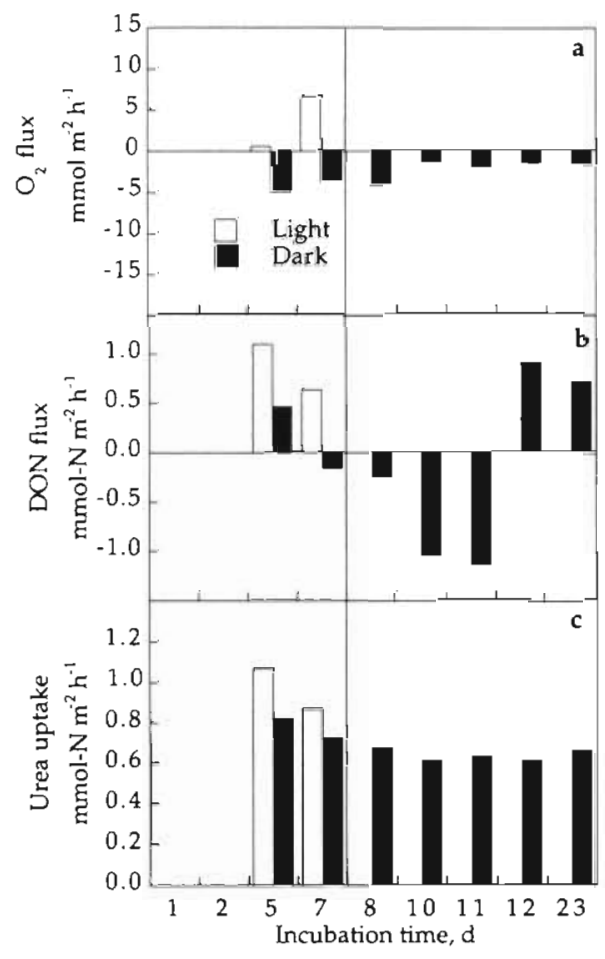

Fig. 4. Net (a) $\mathrm{O}_{2}$ and (b) DON flux rates and (c) net urea uptake rates during the $23 \mathrm{~d}$ of incubation in the prolonged dark experiment. During the first $7 \mathrm{~d}$ the microbial mat was incubated in a 12:12 h light:dark cycle. After Day 7 the chamber was incubated in the dark (indicated by the vertical line)

\section{DISCUSSION}

\section{Growth of the microbial mat}

The microbial mat grew exponentially with $C_{\Upsilon}$ as the carbon source and DON as the nitrogen source during the long-term diel experiment. The growth rate constant was $0.5 \mathrm{~d}^{-1}$ (Fig. 3). We assume that Lyngbya gracialis was the major primary producer, as microscopic inspection of the microbial mat showed that it was the dominating phototrophic organism. The calculated growth rate constant of $0.5 \mathrm{~d}^{-1}$ was comparable to previously reported growth constants for pure cultures of cyanobacteria grown on urea as the only nitrogen source: Anabaena variabilis, $0.5 \mathrm{~d}^{-1}$ and Nostoc muscorum, $0.8 \mathrm{~d}^{-1}$ (Kratz \& Myers 1955) and Pseudoanabaena catenata, $0.7 \mathrm{~d}^{-1}$ (Healey 1977). The average molar $\mathrm{C}: \mathrm{N}$ uptake ratio by the microbial mat of $5.2 \pm 0.54(n=3)$ was in good agreement with the molar C:N ratio of cyanobacteria $(5.0 ;$ Flores et al. 1983) and marine bacteria (4.3 to 5.3; Fagerbakke et al. 1996). This indicated that the microbial mat was not limited by nitrogen during growth, as nitrogen limitation would have resulted in an elevated $C: N$ ratio. 


\section{DON and urea-N uptake}

The microbial mat community was able to take up urea at concentrations exceeding those normally encountered in surface sediments $\left(<26 \mu \mathrm{M} \mathrm{N}_{\text {; Lomstein }}\right.$ et al. 1989, 1998, Lund \& Blackburn 1989, Therkildsen \& Lomstein 1994). It is not possible to give the exact urea concentrations experienced by the microbial mat in the present study, as the size of the diffusive boundary layer below the filter, the diffusive boundary layer above the microbial mat and the thickness of the microbial mat were not measured. However, it was possible to make a rough estimate of the urea concentrations at the lower and upper parts of the microbial mat, respectively, by using Ficks 1' law of diffusion in the different compartments (i.e. the lower diffusive boundary layer, the filter, the microbial mat and the upper diffusive boundary layer). It was assumed that the diffusive boundary layers below the filter and above the mat were both $200 \mu \mathrm{m}$, that the microbial mat was $200 \mu \mathrm{m}$ and that the diffusion coefficient of urea remained constant in the different compartments. The resultant concentration of urea at the lower side of the microbial mat was $159 \mu \mathrm{M}$, whereas the urea concentration at the surface of the microbial mat was $83 \mu \mathrm{M}$. The microorganisms responsible for the uptake of urea were not identified. Pure culture studies with cyanobacteria (Healey 1977, Rai \& Singh 1987), heterotrophic bacteria (Jahns 1992) and studies of mixed natural populations of cyanobacteria (Takamura et al. 1987) have shown that both heterotrophic bacteria and cyanobacteria are able to take up urea. The stimulated urea uptake in the light infers that the process was energy dependent, as previously demonstrated for the heterotrophic marine bacterium Deleya venusta HG1 (Jahns 1992) and several pure cultures of cyanobacteria (Rai \& Singh 1987).

In addition to urea, the microbial mat took up other DON compounds, which were present in the seawater used for the basic medium. Paerl et al. (1993) showed that microbial mats were able to take up DFAA. As DFAA were not present at detectable concentrations in our medium, we can conclude that the microbial mats in the present study were able to take up additional DON constituents other than urea and DFAA.

\section{Dark incubation}

The prolonged dark incubation experiment was performed to study the initial phase of microbial mat break down. After $2 \mathrm{~d}$ in the dark, the $\mathrm{O}_{2}$ uptake was reduced to $50 \%$ of the dark rate measured prior to the dark incubation. It is likely that the decreased $\mathrm{O}_{2}$ uptake $2 \mathrm{~d}$ after the onset of the dark incubation was due to changed substrate availability by the heterotrophic component of the microbial mat.

Interestingly, urea was taken up throughout the entire dark period at a constant rate, while the DON uptake (exclusive urea) increased during the first $3 \mathrm{~d}$ of the dark period. It is not clear whether urea and DON were stored or used as nitrogen sources by the heterotrophic mat community. However, as the microbial mat maintained urea uptake during the first days of the dark incubation, the microbial mat community remained a sink for nitrogen also under heterotrophic conditions.

There was a net release of DON from the microbial mat after $4 \mathrm{~d}$ of dark incubation, which was indicative of a change in the metabolism of the microbial mat community. DON may have originated from the brcakdown of cell material, such as dead cyanobacteria or material from intracellular stores, which were hydrolyzed during cell degradation.

\section{Conclusions}

The microbial mats served as an efficient filter for urea supplied from the bottom chamber in the continuous flow-through system. The urea- $N$ concentrations experienced by the microbial mat in the present study $(\sim 83$ to $159 \mu \mathrm{MN})$ were higher than urea-N concentrations in surface sediment $(<26 \mu \mathrm{M} N)$. In addition, it was shown that the microbial mat took up other DON compounds than urea at rates similar to the urea uptake. It is suggested that microbial mats in shallow marine areas are important sinks for organic as well as inorganic nitrogen.

Acknowledgements. We thank Thomas Kjær for constructive suggestions to the diffusion estimates of urea within the system. This study was funded by grants from the Centre for Strategic Environmental Research in Marine Areas, grant 4.15 and by the EU research programme 'Preserving the Ecosystem' under ROBUST project contract ENV4-CT960218. This work is ELOISE contribution No. |3|. The authors thank 3 anonymous reviewers for constructive criticism.

\section{LITERATURE CITED}

Andersen FO, Kristensen $E$ (1988) The influence of macrofauna on estuarine benthic community metabolism: a microcosm study. Mar Biol 99:591-603

Bauld J (1984) Microbial mat in marginal marine environments: Shark bay, Western Australia and Spencer Gulf, South Australia. In: Cohen Y, Castenholz RW, Halvorson HO (eds) Microbial mats: stromotolites. Alan R. Liss, New York, p 39-58

Bebout BM, Pearl HW, Bauer JE (1994) Nitrogen cycling in microbial mat communities: the quantitative importance of nitrogen fixation and other sources of nitrogen for pri- 
mary productivity. In: Stal LJ, Caumette P (eds) Microbial mats, structure, development and environmental significance. NATO ASI Series Vol G 35, Berlin, p 265-272

Blackburn TH, Henriksen K (1983) Nitrogen cycling in different types of sediments from Danish waters. Limnol Oceanogr 28:477-493

Boucher G, Boucher-Rodoni R (1988) In situ measurement of respiratory metabolism and nitrogen fluxes at the interface of oyster beds. Mar Ecol Prog Ser 44:229-238

Bower CE, Holm-Hansen T (1980) A salicylate-hypochlorite method for determining ammonia in seawater. Can J Fish Aquat Sci 37:794-798

Burdige DJ, Zheng S (1998) The biogeochemical cycling of dissolved organic nitrogen in estuarine sediments. Limnol Oceanogr 43:1796-1813

Castenholz RW (1984) Composition of hot spring microbial mats: a summary. In: Cohen Y, Castenholz RW, Halvorson HO (eds) Microbial mats: stromotolites. Alan R. Liss, New York, p 101-102

Enoksson V, Rüdén-Berg L (1983) A system for determining exchange between sediment and water exemplified by nitrogen flux under controlled oxygen conditions. Environ Biogeochem Ecol Bull 35:243-250

Fagerbakke KM, Heldal M, Norland S (1996) Content of carbon, nitrogen, oxygen, sulphur and phosphorus in native aquatic and cultured bacteria. Aquat Microb Ecol 10:15-27

Flores E, Ramos JL, Herrero A, Guerrero MG (1983) Nitrate assimilation by cyanobacteria. In: Papageorgiou GC, Packer L (eds) Phototrophic prokaryotes: cell differentiations and function. Elsevier/North-Holland, Amsterdam, p $363-387$

Gerdes G, Krumbein WE (1984) Animal communities in recent potential stromatolites of a hypersaline origin. In: Cohen Y, Castenholz RW, Halvorson HO (eds) Microbial mats: stromotolites. Alan R. Liss, New York, p 59-84

Hall POJ, Aller RC (1992) Rapid, small-volume, flow injection analysis for $\mathrm{CO}_{2}$ and $\mathrm{NH}_{4}{ }^{+}$in marine and freshwaters. Limnol Oceanogr 37:1113-1119

Hansen LS, Blackburn TH (1991) Aerobic and anaerobic mineralization of organic material in marine sediment microcosms. Mar Ecol Prog Ser 75:283-291

Hansen LS, Blackburn TH (1992) The effect of algal bloom deposition on sediment respiration and fluxes. Mar Biol 112:147-152

Healey FP (1977) Ammonium and urea uptake by some freshwater algae. Can J Bot 55:61-69

Henriksen K, Hansen JI, Blackburn TH (1980) The influence of benthic infauna on exchange rates of inorganic nitrogen between sediment and water. Ophelia Suppl 1:249-256

Hopkinson CS Jr (1987) Nutrient regeneration in shallowwater sediments of the estuarine plume region of the nearshore Georgia Bight, USA. Mar Biol 94:127-142

Jahns T (1992) Urea uptake by the marine bacterium Deleya venusta HG1. J Gen Microbiol 138:1815-1820

Jørgensen BB, Revsbech NP, Cohen Y (1983) Photosynthesis and structure of benthic microbial mats: microelectrode and SEM studies of four cyanobacterial communities. Lim-

Editorial responsibility: Frede Thingstad,

Bergen, Norway nol Oceanogr 28:1075-1093

Klump JV, Martens CS (1983) Benthic nitrogen regeneration. In: Carpenter EJ, Capone DG (eds) Nitrogen in the marine environment. Academic Press, London, p 411-459

Kratz WA, Myers J (1955) Nutrition and growth of several blue green algae. Am J Bot 42:282-287

Lindroth P, Mopper K (1979) High performance liquid chromatography determination of subpicomole amounts of amino acids by precolumn fluorescence derivatiozation with o-phthaldialdehyde. Anal Chem 51:1667-1675

Lomstein BAa, Blackburn TH, Henriksen K (1989) Aspect of nitrogen and carbon cycling in the northern Bering Shelf Sediment. I. The significance of urea turnover in the mineralization of $\mathrm{NH}_{4}^{+}$. Mar Ecol Prog Ser 57:237-247

Lomstein BAa, Jensen AGU, Hansen JW, Andreasen JB, Hansen LS, Berntsen J, Kunzendorf H (1998) Budgets of sediment nitrogen and carbon cycling in the shallow water of Knebel Vig, Denmark. Aquat Microb Ecol 14:69-80

Lund BAa, Blackburn TH (1989) Urea turnover in a coastal marine sediment measured by a ${ }^{14} \mathrm{C}$-urea short term incubation. J Microbiol Methods 9:297-308

Nishio T, Koike I, Hattori A (1983) Estimates of denitrification and nitrification in coastal and estuarine sediments. Appl Environ Microbiol 45:444-450

Paerl HW, Bebout BM, Joye SB, Des Marais DJ (1993) Microscale characterization of dissolved organic matter production and uptake in marine microbial mat communities. Limnol Oceanogr 38:1150-1161

Price NM, Harrison PJ (1987) Comparison of methods for the analysis of dissolved urea in seawater. Mar Biol 94: $307-317$

Rai AK, Singh S (1987) Kinetic and regulation of urea uptake in Anabaena doliolum and Anacystis nidulans. J Gen Appl Microbiol 33:471-479

Revsbech NP (1989) An oxygen microelectrode with a guard cathode. Limnol Oceanogr 34:474-478

Stal LJ, Gemerden HG, Krumbein WE (1985) Structure and development of a benthic marine microbial mat. FEMS Microbiol Ecol 31:111-125

Sundbäck K, Granéli W (1988) Influence of microphytobenthos on the nutrient flux between sediment and water: a laboratory study. Mar Ecol Prog Ser 43:63-69

Sundbäck K, Enokson V, Granéli W, Petterson K (1991) Influence of sublittoral microphytobenthos on the oxygen and nutrient flux between sediment and water: a laboratory continuous-flow study. Mar Ecol Prog Ser 74:263-279

Takamura N, Iwakuma T, Yasuno $\mathrm{M}$ (1987) Uptake of ${ }^{13} \mathrm{C}$ and ${ }^{15} \mathrm{~N}$ (ammonium, nitrate and urea) by Microcystis in Lake Kasumigaura. J Plankton Res 9:151-165

Therkildsen MS, Lomstein BAa (1994) Seasonal variation in sediment urea turnover in a shallow estuary. Mar Ecol Prog Ser 109:77-82

Waterbury JB (1992) The cyanobacteria - isolation, purification and identification. In: Balows A, Trüper HG, Dworkin M, Harder W, Schleifer KH (eds) The procaryotes: a handbook on the biology of bacteria: ecophysiology, isolation, identification, applications, Vol II, 2nd edn. Springer-Verlag, New York, p 2058-2078

Submitted: July 5, 1999; Accepted: February 15, 2000

Proofs received from author(s): March 22, 2000 